\title{
On Maximal Chains In Partially Ordered Sets With Compatible (Left, Right)- Group Actions
}

Abdul Aali J. Mohammad

Eman M. Tahir

Department of Mathematics

College of Education

Received on: 09/01/2012

University of Mosul, Mosul, Iraq

\section{ABSTRACT}

Accepted on: 19/04/2012

In this paper, we deal with compatible (left, right)-group actions on posets, i.e; $(\mathrm{G}$, $\mathrm{H})$-posets. Our main purpose in this work is to study the maximal chains in $(\mathrm{G}, \mathrm{H})$ posets to observe that this study gives us indications on the type of some $(\mathrm{G}, \mathrm{H})$ actions on posets. Therefore, we shall study the behavior of the $(\mathrm{G}, \mathrm{H})$ actions on chains.

Keywords: maximal chains, partially ordered sets, compatible (left, right) group actions.

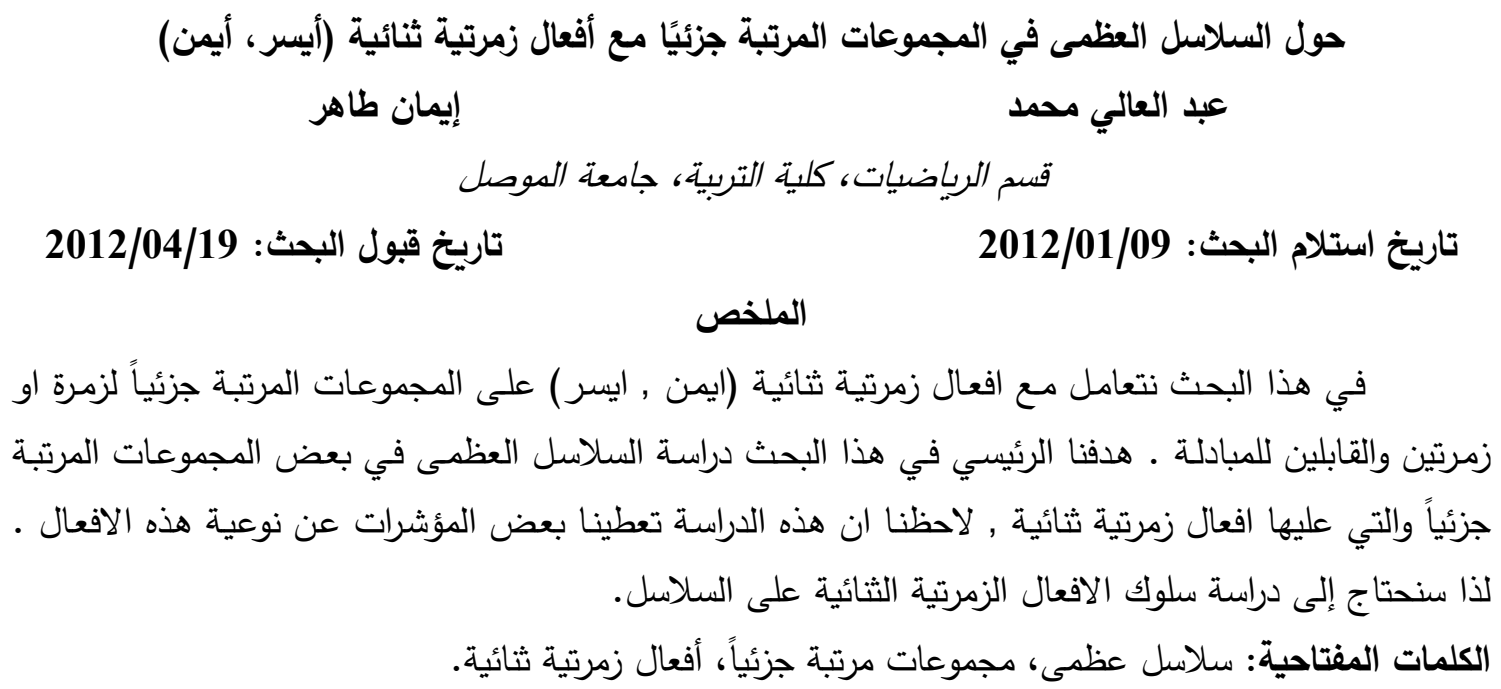

\section{§.1 Introduction:}

The idea of a group action of groups on sets can be extended on sets with additional mathematical structures, specially on posets.

A group action of a group $\mathrm{G}$ in a poset $\mathrm{P}$ can be considered as a group homomorphism $\rho: \mathrm{G} \longrightarrow \operatorname{isom}(\mathrm{P}, \mathrm{P})$ defined by $\rho(\mathrm{g})=\rho \mathrm{g}$ where $\rho \mathrm{g}: \mathrm{P} \rightarrow \mathrm{P}$ is an isomorphism defined by $\rho \mathrm{g}(\mathrm{p})=\mathrm{gp}$ for all $\mathrm{g} \in \mathrm{G}, \mathrm{p} \in \mathrm{P}$.

Such a poset $P$ with a left action of $G$ on it, is called a left G-poset, or simply a Gposet.

Also, since in general there are many such homomorphism $\rho$, so maybe there is many group actions of the group $\mathrm{G}$ on a poset $\mathrm{P}$ (at least the trivial action). Hence, by G-poset we mean only left group action of G on P.

Equivalently, Let $G$ be a group and $P$ a poset, we say that $P$ is a left G-poset if for every $g \in G$ and $p \in P$ there corresponds a unique element $g P \in P$ such that for all $\mathrm{p}, \mathrm{q} \in \mathrm{P}$ and $\mathrm{g}, \mathrm{g}_{1}, \mathrm{~g}_{2} \in \mathrm{G}$;
(i) ep $=\mathrm{p} \quad$ (ii) ${ }^{\mathrm{g}_{2}}\left(\mathrm{~g}_{1} \mathrm{p}\right)=\left(\mathrm{g}_{2} \mathrm{~g}_{1}\right) \mathrm{p}$
(iii) if $p>q$ then $g_{p} g_{q}$

When condition (iii) is neglected, $P$ is called a left G-set.This definition is slightly different from the definition given in [6].Similarly we define a right $\mathrm{H}$-poset. We can conclude that every G-poset $\mathrm{P}$ can be considered as a right H-poset (and conversely) which is defined by: 
$\mathrm{gp}=\mathrm{p}^{\mathrm{g}^{-1}}$ for all $\mathrm{p} \in \mathrm{P}$ and $\mathrm{g} \in \mathrm{G}$.

Also the concept of a group action on sets can be extended to compatible left, right actions on sets. For more details see: [5], [7] and [8].

\section{§.2 Covering (G, H)-posets:}

In this section, we give the definition of the (left, right) group actions on posets, and the covering poset of a given poset.

So, we begin with the formal definition first, before proceeding to explain the intuitive concept behind it.

\section{Definition (2-1): [4].}

A poset $P$ is called $(\mathrm{G}, \mathrm{H})$-poset if $\mathrm{P}$ is a left $\mathrm{G}$-poset, a right $\mathrm{H}$-poset and the two actions are compatible, that is for each $g \in G, h \in H$ and $p \in P$ there corresponds a unique element ${ }^{g} \mathrm{p}^{\mathrm{h}}$ in P such that ${ }^{\mathrm{g}} \mathrm{p}^{\mathrm{h}}={ }^{\mathrm{g}}\left(\mathrm{p}^{\mathrm{h}}\right)=\left({ }^{\mathrm{g}} \mathrm{p}\right)^{\mathrm{h}}$.

Equivalently, let $\mathrm{G}$ and $\mathrm{H}$ be two groups and $\mathrm{P}$ a poset, we say that $\mathrm{P}$ is a $(\mathrm{G}$, $H$ )-poset if for every $g \in G, h \in H$ and $p \in P$ there corresponds a unique element ${ }^{g} p^{h} \in P$ such that

1. ${ }^{\mathrm{e}} \mathrm{p}^{\mathrm{e}}=\mathrm{p}$

2. $P$ is a left G-poset with the action defined by: ${ }^{g} p={ }^{g} p^{e} \forall p \in P, g \in G$.

3. $\mathrm{P}$ is a right $\mathrm{H}$-poset with the action defined by: $\mathrm{p}^{\mathrm{h}}={ }^{\mathrm{e}} \mathrm{p}^{\mathrm{h}} \forall \mathrm{p} \in \mathrm{P}, \mathrm{h} \in \mathrm{H}$.

4. $\left({ }^{\mathrm{g}} \mathrm{p}\right)^{\mathrm{h}}={ }^{\mathrm{g}}\left(\mathrm{p}^{\mathrm{h}}\right) \forall \mathrm{g} \in \mathrm{G}, \mathrm{h} \in \mathrm{H}$ and $\mathrm{p} \in \mathrm{P}$.

5. $\mathrm{p}>\mathrm{q} \Rightarrow{ }^{\mathrm{g}} \mathrm{p}^{\mathrm{h}}>{ }^{\mathrm{g}} \mathrm{q}^{\mathrm{h}} \forall \mathrm{g} \in \mathrm{G}, \mathrm{h} \in \mathrm{H}$ and $\mathrm{p}, \mathrm{q} \in \mathrm{P}$.

When condition (5) is neglected, P is called a $(\mathrm{G}, \mathrm{H})$-set. For more details see: [5], [6] and[8].

\section{Example (2-2)}

Let the additive group $\mathrm{Z}$ acts on the set of the real numbers $\mathrm{R}$ by the action :

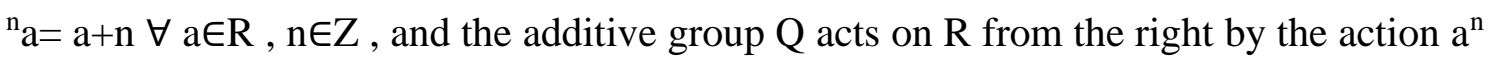
$=\mathrm{a}-\mathrm{n} \forall \mathrm{a} \in \mathrm{R}, \mathrm{n} \in \mathrm{Q}$, then $\mathrm{R}$ is $\mathrm{a}(\mathrm{Z}, \mathrm{Q})$-poset.

Also, there exists a G-poset $\mathrm{P}$ which is also a right $\mathrm{H}$-poset, but it's not a $(\mathrm{G}, \mathrm{H})$ poset, as in the following example; let $\mathrm{G}=\mathrm{H}=\mathrm{C}_{2}=\{\mathrm{e}, \mathrm{a}\}$ and $\mathrm{P}=\{\mathrm{x}, \mathrm{y}, \mathrm{z}, \mathrm{w}, \mathrm{t}, \mathrm{r}\}$ is a poset with $\mathrm{x}<\mathrm{y}, \mathrm{z}<\mathrm{w}, \mathrm{t}<\mathrm{r}$. Then, $\mathrm{P}$ is a G-poset with the action defined by : ${ }^{\mathrm{a}} \mathrm{x}=\mathrm{z}$, ${ }^{\mathrm{a}} \mathrm{y}=\mathrm{w},{ }^{\mathrm{a}} \mathrm{t}=\mathrm{t},{ }^{\mathrm{a}} \mathrm{r}=\mathrm{r},{ }^{\mathrm{e}} \mathrm{p}=\mathrm{p} \forall \mathrm{p} \in \mathrm{P}$, and a right $\mathrm{H}$-poset with the action defined by : $\mathrm{x}^{\mathrm{a}}=\mathrm{x}, \mathrm{y}^{\mathrm{a}}=\mathrm{y}, \mathrm{z}^{\mathrm{a}}=\mathrm{r}, \quad \mathrm{wa}=\mathrm{t}, \mathrm{pe}=\mathrm{p} \forall \mathrm{p} \in \mathrm{P}$. But, $\mathrm{P}$ is not $(\mathrm{G}, \mathrm{H})$-poset, that is since $\left({ }^{\mathrm{a}} \mathrm{z}\right)^{\mathrm{a}}=\mathrm{z}^{\mathrm{a}}=\mathrm{t}$ and ${ }^{\mathrm{a}}\left(\mathrm{z}^{\mathrm{a}}\right)={ }^{\mathrm{a}} \mathrm{r}=\mathrm{r}$.

Remark (2-3): $\mathrm{H}$ on $\mathrm{P}$.

Any G-poset $\mathrm{P}$ can be considered as $(\mathrm{G}, \mathrm{H})$-poset with the trivial right action of

Also, from the definition above, we see that a left G-poset $\mathrm{P}$ is one left action of $\mathrm{G}$ on $\mathrm{P}$. But, for $(\mathrm{G}, \mathrm{H})$-poset $\mathrm{P}$ there are two compatible group actions one is from the left and the other from the right.

Definition (2-4): [2]

Let $\mathrm{P}$ be a poset. We say that the element a of $\mathrm{P}$ covers the element $\mathrm{b}$ of $\mathrm{P}$ if $a>b$ and there is no element $c \in P$ such that $a>c>b$.

\section{Proposition (2-5):}

Let $\mathrm{P}$ be $\mathrm{a}(\mathrm{G}, \mathrm{H})$-poset and $\mathrm{a}, \mathrm{b} \in \mathrm{P}$ with a covers $\mathrm{b}$, then ${ }^{\mathrm{g}} \mathrm{a}^{\mathrm{h}}$ covers ${ }^{\mathrm{g}} \mathrm{b}^{\mathrm{h}} \forall \mathrm{g} \in \mathrm{G}$ and $h \in H$. 


\section{Proof:}

Suppose that ${ }^{\mathrm{g}} \mathrm{a}^{\mathrm{h}}$ does not cover ${ }^{\mathrm{g}} \mathrm{b}^{\mathrm{h}}$, then there exists, at least, an element $\mathrm{c} \in \mathrm{P}$ such that ${ }^{\mathrm{g}} \mathrm{a}^{\mathrm{h}}>\mathrm{c}>{ }^{\mathrm{g}} \mathrm{b}^{\mathrm{h}}$. Hence, $a>^{g^{-1}} c^{h^{-1}}>b$ and this is a contradiction. Therefore, ${ }^{\mathrm{g}} \mathrm{a}^{\mathrm{h}}$ covers $\mathrm{g}^{\mathrm{h}}$.

\section{Definition (2-6): [1].}

Let $\mathrm{P}$ be a poset. Then, the set, $\mathrm{C}(\mathrm{P})=\{(\mathrm{a}, \mathrm{b}): \mathrm{a}$ covers $\mathrm{b}\} \subset \mathrm{P} \times \mathrm{P}$, is called the covering poset of $\mathrm{P}$.

\section{Proposition (2-7): [1].}

Let $(\mathrm{P}, \geq)$ be a poset, then $\left((P), \geq_{C}\right)$ is a poset such that: for all $(\mathrm{a}, \mathrm{b})$,

$$
\left(a^{\prime}, b^{\prime}\right) \in \mathrm{C}(\mathrm{P}),(a, b) \underset{C}{\geq}\left(a, b^{\prime}\right) \text { if and only if } \quad\left\{(a, b)=\left(a^{\prime}, b^{\prime}\right) \text { or } b \geq a^{\prime}\right\}
$$

\section{Theorem (2-8):}

Let $\mathrm{P}$ be a $(\mathrm{G}, \mathrm{H})$-poset. Then $\mathrm{C}(\mathrm{P})$ is also a $(\mathrm{G}, \mathrm{H})$-poset with an action defined by; ${ }^{\mathrm{g}}(\mathrm{a}, \mathrm{b})^{\mathrm{h}}=\left({ }^{\mathrm{g}} \mathrm{a}^{\mathrm{h}},{ }^{\mathrm{g}} \mathrm{b}^{\mathrm{h}}\right) \quad \forall(\mathrm{a}, \mathrm{b}) \in \mathrm{C}(\mathrm{P}), \mathrm{g} \in \mathrm{G}$ and $\mathrm{h} \in \mathrm{H}$.

\section{Proof:}

(i) ${ }^{\mathrm{e}}(\mathrm{a}, \mathrm{b})^{\mathrm{e}}=\left({ }^{\mathrm{e}} \mathrm{a}^{\mathrm{e}}, \mathrm{e}^{\mathrm{e}}\right)=(\mathrm{a}, \mathrm{b}) \quad \forall(\mathrm{a}, \mathrm{b}) \in \mathrm{C}(\mathrm{P})$.

(ii) ${ }^{\mathrm{g} 1}\left(\mathrm{~g} 2(\mathrm{a}, \mathrm{b})^{\mathrm{h} 2}\right)^{\mathrm{h} 1}=\left({ }^{\mathrm{g} 1}\left(\mathrm{~g}^{2} \mathrm{a}^{\mathrm{h} 2}\right)^{\mathrm{h} 1},{ }^{\mathrm{g} 1}\left(\mathrm{~g}^{\mathrm{g}} \mathrm{b}^{\mathrm{h} 2}\right)^{\mathrm{h} 1}\right)=\left({ }^{\mathrm{g} 1 \mathrm{~g} 2} \mathrm{a}^{\mathrm{h} 2 \mathrm{~h} 1},{ }^{\mathrm{g} 1 \mathrm{~g} 2} \mathrm{~b}^{\mathrm{h} 2 \mathrm{~h} 1}\right)={ }^{(\mathrm{g} 1 \mathrm{~g} 2)}(\mathrm{a}, \mathrm{b})^{(\mathrm{h} 2 \mathrm{~h} 1)}$

$\forall(\mathrm{a}, \mathrm{b}) \in \mathrm{C}(\mathrm{P})(\mathrm{g} 1, \mathrm{~h} 1),(\mathrm{g} 2, \mathrm{~h} 2) \in \mathrm{G} \times \mathrm{H}$.

(iii) For all $(a, b),\left(a^{\prime}, b^{\prime}\right) \in C(P),(g, h) \in G \times H$, with $\left(a^{\prime}, b^{\prime}\right) \geq(a, b)$.

Then $b^{\prime} \geq a$. So ${ }^{g} b^{\prime h} \geq{ }^{g} a^{h}$. Since $(a, b),\left(a^{\prime}, b^{\prime}\right) \in C(P)$.

Then $\left({ }^{\mathrm{g}} \mathrm{a}^{\mathrm{h}},{ }^{\mathrm{g}} \mathrm{b}^{\mathrm{h}}\right),\left({ }^{\mathrm{g}} \mathrm{a}^{\prime \mathrm{h}},{ }^{\mathrm{g}} \mathrm{b}^{\text {hh }}\right) \in \mathrm{C}(\mathrm{P})$. That is $\left({ }^{\mathrm{g}} \mathrm{a}^{\mathrm{h}}, \mathrm{g}^{\mathrm{g}} \mathrm{b}^{\mathrm{h}}\right) \geq\left({ }^{\mathrm{g}} \mathrm{a}^{\mathrm{h}},{ }^{\mathrm{g}} \mathrm{b}^{\mathrm{h}}\right)$. Hence $\mathrm{g}^{\mathrm{g}}\left(\mathrm{a}^{\prime}, \mathrm{b}^{\prime}\right)^{\mathrm{h}} \mathrm{g}^{\mathrm{g}}(\mathrm{a}, \mathrm{b})^{\mathrm{h}}$. Therefore, $\mathrm{C}(\mathrm{P})$ is a $(\mathrm{G}, \mathrm{H})$-poset .

\section{§3. (G, H)-Chains:}

In this section, we study the (left, right) group actions on chains and when the trivial action is the only one.

Definition (3-1): [2].

A poset $P$ is called a chain (or totally ordered set) if; for all $a, b \in P: a \geq b$ or $b \geq a$.

Equivalently, the poset $\mathrm{P}$ is called a chain if for every two different elements $a, b$ of $\mathrm{P}$ either $\mathrm{a}>\mathrm{b}$ or $\mathrm{b}>\mathrm{a}$.

From the definition above, we conclude that every element of a chain covers, at most, one element and covered at most by one element. Also, any chain has, at most, one maximal element 1 and one minimal element 0 .

\section{Remark (3-2): [2].}

Any chain $\mathrm{X}$ of $\mathrm{n}$ elements is isomorphic to the set of natural numbers $\underline{n}=\{1,2, \ldots, n\}$. that is there exists a bijection function $f: X \rightarrow \underline{n}$ suchthat:

$$
f\left(x_{1}\right) \geq f\left(x_{2}\right) \text { if and only if } x_{1} \geq x_{2} .
$$

\section{Theorem (3-3):}

Let $X=\left\{x_{i}\right\}_{i \in I}$ be a $(\mathrm{G}, \mathrm{H})$-chain and I be a set of successive integers with ... $x_{i-1}<x_{i}<x_{i+1}<\ldots$

If ${ }^{g} \mathrm{X}_{\mathrm{i}}{ }^{\mathrm{h}}=\mathrm{x}_{\mathrm{j}}$ then, ${ }^{\mathrm{g}} \mathrm{X}^{\mathrm{hi+r}}=\mathrm{x}_{\mathrm{j}+\mathrm{r}} \forall \mathrm{i}, \mathrm{j}, \mathrm{i}+\mathrm{r}, \mathrm{j}+\mathrm{r} \in \mathrm{I}$. 


\section{Proof:}

(i) Let $i+1, j+1 \in I$. Since, $\mathrm{X}$ is a chain, then $x_{i+1}$ covers $x_{i}$ and by proposition (2-3), ${ }^{\mathrm{g}} \mathrm{X}_{\mathrm{i}+1} \mathrm{covers}^{\mathrm{g}} \mathrm{X}_{\mathrm{i}}$.

Since, ${ }^{g} X_{i}{ }_{i}=x j$ then, $x_{j+1}$ covers ${ }^{g} X_{i}{ }_{i}$. So ${ }^{g} X_{i}{ }_{i}=x_{j+1}$.

(ii) Now, we shall use the mathematical induction to prove that ${ }^{g} \mathrm{X}_{i+1}=\mathrm{x}_{j+1}$ for $\mathrm{i}$ $=1$. Suppose $\mathrm{g} x_{i+n}^{h}=\mathrm{x}_{\mathrm{j}+\mathrm{n}}$ for $\mathrm{r}=\mathrm{n}$ and $\mathrm{i}+\mathrm{n}, \mathrm{j}+\mathrm{n} \in \mathrm{I}$. Since, $\mathrm{X}$ is a chain, then $\mathrm{x}_{\mathrm{i}+\mathrm{n}+1}$ covers $\mathrm{X}_{\mathrm{i}+\mathrm{n}}$. So, ${ }^{\mathrm{g}} \mathrm{X}_{\mathrm{i}+\mathrm{n}+1}$ covers ${ }^{\mathrm{g}} \mathrm{X}_{\mathrm{i}+\mathrm{n}}$.Now, from ${ }^{\mathrm{g}} \mathrm{X}_{\mathrm{i}+\mathrm{n}}={ }^{\mathrm{g}} \mathrm{X}_{\mathrm{j}+\mathrm{n}}$ we have ${ }^{\mathrm{g}} \mathrm{X}_{\mathrm{i}+\mathrm{n}+1}=\mathrm{X}_{j+n+1}$. Therefore , ${ }^{\mathrm{g}} \mathrm{X}_{\mathrm{i}+\mathrm{r}}=\mathrm{x}_{\mathrm{j}+\mathrm{r}} \forall \mathrm{i}, \mathrm{j}, \mathrm{i}+\mathrm{r}, \mathrm{j}+\mathrm{r} \in \mathrm{I}$.

\section{Lemma (3-4):} $\mathrm{x}_{\mathrm{i}} \in \mathrm{X}$.

Let $\mathrm{X}$ be a $(\mathrm{G}, \mathrm{H})$-chain and $(\mathrm{g}, \mathrm{h}) \in \mathrm{G} \times \mathrm{H}$. If ${ }^{\mathrm{g}} \mathrm{X}_{\mathrm{i}}{ }_{\mathrm{h}}=\mathrm{x}_{\mathrm{t}}$ and $\mathrm{x}_{\mathrm{i}}<\mathrm{x}^{\mathrm{t}}$, then ${ }^{\mathrm{g}-1} \mathrm{x}_{\mathrm{i}}{ }^{\mathrm{h}-1}<\mathrm{x}_{\mathrm{i}} \forall$

Proof:

$$
\begin{aligned}
& { }^{g} X_{i}{ }^{h}=x_{t} \Rightarrow g^{-1}\left({ }^{g} X_{i}{ }^{h} h^{h^{-1}}={ }^{g^{-1}} x_{t}{ }^{-1} \Rightarrow g^{-1}\left({ }^{g} x_{i}{ }^{h} h^{h h^{-1}}={ }^{g^{-1}} x_{t} h^{-1} \Rightarrow\right.\right. \\
& \mathrm{g}^{-1} \mathrm{x}_{\mathrm{t}} \mathrm{h}^{-1}=\mathrm{x}_{\mathrm{i}} \text {. } \\
& \text { Also, } x_{i}<x_{t} \Rightarrow{ }^{g^{-1}} x_{i} h^{-1}<g^{-1} x_{t}{ }^{-1} \text {. Therefore, }{ }^{g^{-1}} x_{i}{ }^{-1}<x_{i}
\end{aligned}
$$

\section{Definition (3-5):}

Let $\mathrm{P}$ be a $(\mathrm{G}, \mathrm{H})$-poset. For each $\mathrm{p} \in \mathrm{P}$ the set:

Stab $(\mathrm{G}, \mathrm{H})(\mathrm{p})=\left\{(\mathrm{g}, \mathrm{h}) \in \mathrm{G} \times \mathrm{H}:{ }^{\mathrm{g}} \mathrm{p}^{\mathrm{h}}=\mathrm{p}\right\}$ is called the stabilizer of $\mathrm{p}$.

\section{Proposition (3-6):}

Let $\mathrm{X}$ be a $(\mathrm{G}, \mathrm{H})$-chain and $(\mathrm{g}, \mathrm{h}) \in \mathrm{G} \times \mathrm{H}$ with $g^{-1}=g$ and $\mathrm{h}^{-1}=\mathrm{h}$. Then, $(\mathrm{g}, \mathrm{h}) \in \operatorname{Stab}_{(\mathrm{G}, \mathrm{H})}\left(\mathrm{x}_{\mathrm{i}}\right) \quad$ for all $\mathrm{x}_{\mathrm{i}} \in \mathrm{X}$.

Let ${ }^{g} x_{i}{ }^{h}=x_{t}$. Then, $x_{i}={ }^{g^{-1}} x_{t}{ }^{-1}$. So, $x_{i}=$ gxth. Suppose that $x_{i} \neq x_{t}$. Then, either $\mathrm{x}_{\mathrm{i}}<\mathrm{x}_{\mathrm{t}}$ or $\mathrm{x}_{\mathrm{t}}<\mathrm{x}_{\mathrm{i}}$. If $\mathrm{x}_{\mathrm{i}}<\mathrm{x}_{\mathrm{t}}$ then ${ }^{\mathrm{g}} \mathrm{x}_{\mathrm{i}}{ }^{\mathrm{h}}<\mathrm{g}^{\mathrm{g}} \mathrm{x}_{\mathrm{t}}{ }^{\mathrm{h}}$.So, $\mathrm{x}_{\mathrm{t}}<\mathrm{x}_{\mathrm{i}}$. That is a contradiction.

Similarly, we have a contradiction if $x_{t}<x_{i}$. Hence, since $X$ is a chain, then $x_{i}=$ $\mathrm{X}_{\mathrm{t}}$. So ${ }^{\mathrm{g}} \mathrm{X}_{\mathrm{i}}^{\mathrm{h}}=\mathrm{X}_{\mathrm{i}}$.

Therefore, $(\mathrm{g}, \mathrm{h}) \in \operatorname{Stab}(\mathrm{G}, \mathrm{H})\left(\mathrm{x}_{\mathrm{i}}\right)$ for all $\mathrm{x}_{\mathrm{i}} \in \mathrm{X}$.

\section{Theorem (3-7):}

Let $(\mathrm{X}, \leq)$ be a $(\mathrm{G}, \mathrm{H})$-chain. Then, the $(\mathrm{G}, \mathrm{H})$ action on $\mathrm{X}$ is only the trivial action if $X$ has 0 or 1 .

\section{Proof:}

(i) Let $0=\mathrm{x}_{1} \in \mathrm{X}$ and $(\mathrm{g}, \mathrm{h}) \in \mathrm{G} \times \mathrm{H}$. Suppose that ${ }^{\mathrm{g}} \mathrm{X}_{1}{ }^{\mathrm{h}} \neq \mathrm{x} 1$, then $\mathrm{x}_{1}<{ }^{\mathrm{g}} \mathrm{X}_{1}{ }^{\mathrm{h}}\left[\mathrm{x}_{1}=0\right]$. Also, ${ }^{\mathrm{g}^{-1}} \mathrm{x}_{\mathrm{i}} \mathrm{h}^{-1}<\mathrm{x}_{1}=0$. So, this is a contradiction.

So, ${ }^{g} \mathrm{X}_{1}{ }^{\mathrm{h}}=\mathrm{x}_{1}$. Now, from theorem (3-3) we have ${ }^{\mathrm{g}} \mathrm{X}_{\mathrm{i}}{ }^{\mathrm{h}}=\mathrm{x}_{\mathrm{i}}$ for all $\mathrm{x}_{\mathrm{i}} \in \mathrm{X}$ and $(\mathrm{g}, \mathrm{h}) \in \mathrm{G} \times \mathrm{H}$.

(ii) Let $1=\mathrm{x}_{1} \in \mathrm{X}$ and $(\mathrm{g}, \mathrm{h}) \in \mathrm{G} \times \mathrm{H}$. Suppose that ${ }^{\mathrm{g}} \mathrm{X}_{1}{ }^{\mathrm{h}} \neq \mathrm{x}_{1}$, then ${ }^{\mathrm{g}} \mathrm{X}_{1}{ }^{\mathrm{h}}<\mathrm{x}_{1}\left[\mathrm{x}_{1}=1\right]$. Also, $\mathrm{x}_{1}<\mathrm{g}^{-1} \mathrm{x}_{1} \mathrm{~h}^{-1}$. So, this is a contradiction.

So, ${ }^{g} \mathrm{X}_{1}{ }^{\mathrm{h}}=\mathrm{x}_{1}$. Now, from theorem (3-3) we have ${ }^{\mathrm{g}} \mathrm{X}_{\mathrm{i}}{ }^{\mathrm{h}}=\mathrm{X}_{\mathrm{i}}$ for all $\mathrm{x}_{\mathrm{i}} \in \mathrm{X}$ and $(\mathrm{g}, \mathrm{h}) \in \mathrm{G} \times \mathrm{H}$. 


\section{Corollary (3-8):}

H)-chain.

Let $P=\left\{p_{1}, p_{2}, \ldots, p_{n}\right\}$ be a $(G, H)$-chain with $p_{1}>p_{2}>\ldots>p_{n}$. Then, $P$ is a trivial $(G$,

\section{§.4 Maximal chains:}

Finally, in this section, we will study the maximal chains in $(\mathrm{G}, \mathrm{H})$-posets and we shall observe that the study of these kinds of chains gives us some indications on the type of some group actions on posets.

Definition (4-1): [2].

Let $\mathrm{P}$ be a poset and $X=\left\{x_{i}, x_{i+1}, \ldots, x_{j}\right\} \subseteq P$ be a chain such that $\mathrm{x}_{\mathrm{i}}<\mathrm{x}_{\mathrm{i}+1}<\ldots<\mathrm{x}_{\mathrm{j}}$, then $\mathrm{X}$ is called a maximal chain in $\mathrm{P}$ if and only if:

(i) There is no element as $\mathrm{c} \in \mathrm{P}$ such that: $\mathrm{x}_{\mathrm{i}}<\mathrm{x}_{\mathrm{i}+1}<\ldots<\mathrm{c}<\ldots<\mathrm{x}_{\mathrm{j}}$.

(ii) There is no element as $k \in P$ such that: $k<x_{i}$ or $x_{j}<k$.

\section{Proposition (4-2):}

Let $\mathrm{P}$ be a $(\mathrm{G}, \mathrm{H})$-poset and $\mathrm{Y}$ be a maximal chain in $\mathrm{P}$. Then, ${ }^{\mathrm{g}} \mathrm{Y}^{\mathrm{h}}$ is also a maximal chain in $\mathrm{P}$ with $\left.\right|^{\mathrm{g}} \mathrm{Y}^{\mathrm{h}}|=| \mathrm{Y} \mid$.

\section{Proof:}

(i) Since $Y$ is a maximal chain in $P$, so we can say $Y=\left\{x_{i}, x_{i+1}, \ldots, x_{j}\right\}$ such that $x_{r+1}$ covers $\mathrm{x}_{\mathrm{r}}$ for all $\mathrm{i}<\mathrm{r}<\mathrm{j}$. So ${ }^{\mathrm{g}} \mathrm{Y}^{\mathrm{h}}=\left\{{ }^{\mathrm{g}} \mathrm{X}_{\mathrm{i}}{ }^{\mathrm{h}},{ }^{\mathrm{g}} \mathrm{X}_{\mathrm{i}+1}{ }^{\mathrm{h}}, \ldots .,{ }^{\mathrm{g}} \mathrm{X}_{\mathrm{j}}{ }^{\mathrm{h}}\right\}$ for all $(\mathrm{g}, \mathrm{h}) \in \mathrm{G} \times \mathrm{H}$. Hence, ${ }^{\mathrm{g}} \mathrm{X}_{\mathrm{i}}^{\mathrm{h}}<{ }^{\mathrm{g}} \mathrm{X}_{\mathrm{i}+1}{ }^{\mathrm{h}}<\ldots<{ }^{\mathrm{g}} \mathrm{X}_{\mathrm{j}}{ }^{\mathrm{h}}$.Suppose that there exists an element as $\mathrm{c} \in \mathrm{P}$ such that ${ }^{\mathrm{g}} \mathrm{X}_{\mathrm{i}}{ }^{\mathrm{h}}<{ }^{\mathrm{g}} \mathrm{X}_{\mathrm{i}+1}{ }^{\mathrm{h}}<\ldots<\mathrm{c}<\ldots<{ }^{\mathrm{g}} \mathrm{X}_{\mathrm{j}}{ }^{\mathrm{h}}$.

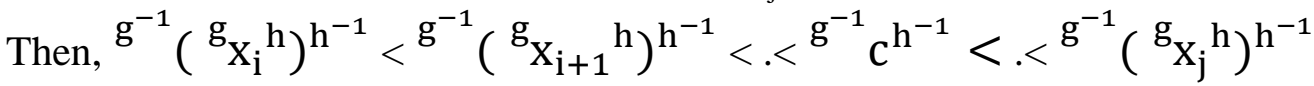

That is $\mathrm{x}_{\mathrm{i}}<\mathrm{x}_{\mathrm{i}+1}<\ldots<\mathrm{g}^{-1} \mathrm{ch}^{\mathrm{h}^{-1}}<\ldots<\mathrm{x}_{\mathrm{j}}$ and this is a contradiction since $\mathrm{Y}$ is a maximal chain.

(ii) Suppose that there exists an element $\mathrm{b} \in \mathrm{P}$ such that $\mathrm{b}<$ gxih then:

$\mathrm{b} \leq{ }^{\mathrm{g}} \mathrm{X}_{\mathrm{i}}{ }^{\mathrm{h}} \Rightarrow{ }^{\mathrm{g}^{-1}} \mathrm{~b}^{\mathrm{h}^{-1}}<\mathrm{x}_{\mathrm{i}} \Rightarrow{ }^{\mathrm{g}^{-1}} \mathrm{~b}^{\mathrm{h}^{-1}}=\mathrm{x}_{\mathrm{i}} \Rightarrow \mathrm{b}={ }^{\mathrm{g}} \mathrm{X}_{\mathrm{i}}{ }^{\mathrm{h}}$.

Similarly, if gxih $\leq \mathrm{a}$ then $\mathrm{gxjh}=\mathrm{a}$. Therefore, $\mathrm{gYh}$ is a maximal chain.

Now, let the map $\mathrm{f}: \mathrm{Y} \rightarrow \mathrm{gYh}$ is defined by: $\mathrm{f}(\mathrm{y})=\mathrm{gYh} \forall \mathrm{y} \in \mathrm{Y}$.

$\mathrm{f}$ is injective map since $: \mathrm{f}(\mathrm{y} 1)=\mathrm{f}(\mathrm{y} 2) \Rightarrow{ }^{\mathrm{g}} \mathrm{y}_{1}{ }^{\mathrm{h}}={ }^{\mathrm{g}} \mathrm{y}_{2}{ }^{\mathrm{h}} \Rightarrow \mathrm{y}_{1}=\mathrm{y}_{2}$.

Also $f$ is onto since if $x \in^{g} Y^{h}$ then there exits $y \in Y$ such that $\mathrm{x}={ }^{\mathrm{g}} \mathrm{y}^{\mathrm{h}}$. Hence, $\mathrm{f}$ is bijection and $|\mathrm{Y}|=\left|{ }^{\mathrm{g}} \mathrm{Y}^{\mathrm{h}}\right|$

\section{Definition (4-3): [2].}

Let $\mathrm{P}$ be a poset and $\mathrm{x} \in \mathrm{P}$. Then, the subset $\mathrm{C}$ of $\mathrm{P}$ is called a cutset of the element $\mathrm{x}$ in $\mathrm{P}$ if every element of $\mathrm{C}$ is not comparable with $\mathrm{x}$ and all the maximal chains in $\mathrm{P}$ cut with $\mathrm{C} \cup\{\mathrm{x}\}$. We shall denote to this set by cut $x$.

\section{Proposition (4-4):}

Let $\mathrm{P}$ be a $(\mathrm{G}, \mathrm{H})$-poset and $\mathrm{C}$ is the cutset of $\mathrm{x} \in \mathrm{P}$. Then, ${ }^{\mathrm{g}} \mathrm{C}^{\mathrm{h}}$ is the cutset of gxh. That is ${ }^{g} C^{h}=$ cut $^{g} X^{h}$.

\section{Proof:}


Let $y \in$ cut ${ }^{g} x^{h}$ then ${ }^{g^{-1}} y^{h^{-1}}$ is not comparable with ${ }^{g} x^{h}$. So ${ }^{-1} y^{h^{-1}}$ is not comparable with $\mathrm{x}$. That is ${ }^{\mathrm{g}^{-1}} \mathrm{y}^{\mathrm{h}^{-1}} \in \mathrm{C}$. So, $\mathrm{g}\left({ }^{\mathrm{g}^{-1}} \mathrm{y}^{\mathrm{h}^{-1}}\right) \mathrm{h} \in{ }^{\mathrm{g}} \mathrm{C}^{\mathrm{h}}$. That is $\mathrm{y} \in{ }^{\mathrm{g}} \mathrm{C}^{\mathrm{h}}$. Hence, cut ${ }^{\mathrm{g}} \mathrm{X}^{\mathrm{h}} \subseteq{ }^{\mathrm{g}} \mathrm{C}^{\mathrm{h}}$.

Now let ${ }^{\mathrm{g}} \mathrm{S}^{\mathrm{h}} \in{ }^{\mathrm{g}} \mathrm{C}^{\mathrm{h}}$. Then, $\mathrm{s} \in \mathrm{C}$. So, $\mathrm{s}$ is not comparable with $\mathrm{x}$. that is ${ }^{g} S^{\mathrm{h}}$ is not comparable with ${ }^{\mathrm{g}} \mathrm{X}^{\mathrm{h}}$. So ${ }^{\mathrm{g}} \mathrm{S}^{\mathrm{h}} \in$ cut ${ }^{\mathrm{g}} \mathrm{X}^{\mathrm{h}}$.

Therefore, ${ }^{g} C^{\mathrm{h}}=$ cut ${ }^{\mathrm{g}} \mathrm{X}^{\mathrm{h}}$.

\section{Theorem (4-5):}

Let $\mathrm{P}$ be a finite $(\mathrm{G}, \mathrm{H})$-poset with $\mathrm{P}(\mathrm{M})=\left\{\mathrm{M}_{1}, \mathrm{M}_{2}, \ldots, \mathrm{M}_{\mathrm{n}}\right\}$ be the set of the maximal chains in $\mathrm{P}$ with $\left|M_{i}\right|=\left|M_{j}\right|$ if and only if $\mathrm{i}=\mathrm{j}$. Then, the trivial action is the only action of $(\mathrm{G}, \mathrm{H})$ on $\mathrm{P}$.

\section{Proof:}

To prove this theorem, we must first prove that ${ }^{\mathrm{g}} \mathbf{M}_{\mathrm{i}}^{\mathrm{h}}=\mathrm{M}_{\mathrm{i}}$ for $1 \leq \mathrm{i} \leq \mathrm{n}$, after that we must show that ${ }^{\mathrm{g}} \mathrm{x}^{\mathrm{h}}=\mathrm{x}$ for all $\mathrm{x} \in \mathrm{Mi}$ and $(\mathrm{g}, \mathrm{h}) \in \mathrm{G} \times \mathrm{H}$.

\section{First part:}

Our argument proceeds by mathematical induction on the number $\mathrm{n}$ to prove that ${ }^{\mathrm{g}} \mathrm{M}_{\mathrm{i}}^{\mathrm{h}}=\mathrm{M}_{\mathrm{i}}$ for all $1 \leq \mathrm{i} \leq \mathrm{n}$.

Let $\left|\mathrm{M}_{\mathrm{i}}\right|=\mathrm{r}_{\mathrm{i}}, \quad \forall 1 \leq \mathrm{i} \leq \mathrm{n}$ such that $\mathrm{r}_{1}<\mathrm{r}_{2}<\ldots<\mathrm{r}_{\mathrm{n}}$.

(i) Let $\mathrm{n}=2$. That is $\mathrm{P}(\mathrm{M})=\left\{\mathrm{M}_{1}, \mathrm{M}_{2}\right\}$ with $\left|M_{1}\right| \neq\left|M_{2}\right|$.

Suppose that ${ }^{\mathrm{g}} \mathrm{M} 1^{\mathrm{h}} \neq \mathrm{M}_{1}$. By proposition(4-2) ${ }^{\mathrm{g}} \mathrm{M}_{1}{ }^{\mathrm{h}}$ is a maximal chain and $\left|{ }^{\mathrm{g}} \mathrm{M}_{1}{ }^{\mathrm{h}}\right|$ $=\left|M_{1}\right|$,then ${ }^{\mathrm{g}} \mathrm{M}_{1}{ }^{\mathrm{h}} \in \mathrm{P}(\mathrm{M})$. So ${ }^{\mathrm{g}} \mathrm{M}_{1}{ }^{\mathrm{h}}=\mathrm{M}_{2}$. Hence, $\left|{ }^{\mathrm{g}} \mathrm{M}_{1}{ }^{\mathrm{h}}\right|=\left|\mathrm{M}_{2}\right|=\left|\mathrm{M}_{1}\right|$. That is $\mathrm{a}$ contradiction.So, ${ }^{\mathrm{g}} \mathbf{M}_{1}{ }^{\mathrm{h}}=\mathrm{M}_{1}$. Similarly, we have ${ }^{\mathrm{g}} \mathbf{M}_{2}{ }^{\mathrm{h}}=\mathrm{M}_{2}$.

(ii) Now assume that $\mathrm{n}=\mathrm{k}$ with ${ }^{\mathrm{g}} \mathrm{Mi}^{\mathrm{h}}=\mathrm{M}_{\mathrm{i}}$ for all $1 \leq \mathrm{i} \leq \mathrm{k}$.

Let $\mathrm{n}=\mathrm{k}+1$. Since ${ }^{\mathrm{g}} \mathrm{Mi}^{\mathrm{h}}=\mathrm{M}_{\mathrm{i}}$ for all $1 \leq \mathrm{i} \leq \mathrm{k}$.

Suppose that ${ }^{\mathrm{g}} \mathbf{M}_{\mathrm{k}+1}{ }^{\mathrm{h}} \neq \mathrm{M}_{\mathrm{k}+1}$ then, ${ }^{\mathrm{g}} \mathbf{M}_{\mathrm{k}+1}{ }^{\mathrm{h}}=\mathrm{M}_{\mathrm{j}}$ for some $1 \leq \mathrm{j} \leq \mathrm{k}$. So, $\left|{ }^{\mathrm{g}} \mathbf{M}_{\mathrm{k}+1}{ }^{\mathrm{h}}\right|=$ $\left|M_{j}\right|=r_{j}$. But $\left|{ }^{g} M_{k+1}{ }^{h}\right|=\left|M_{k+1}\right|=r_{k+1}$. Hence, $r_{j}=r_{k+1}$, that is $j=k+1$, and this is a contradiction since $\mathrm{k}+1>\mathrm{j}$. So, ${ }^{\mathrm{g}} \mathrm{M}_{\mathrm{k}+1}{ }^{\mathrm{h}}=\mathrm{M}_{\mathrm{k}+1}$.

\section{Second part:}

Since $\left\{M_{i}\right\}_{i=1}^{n}$ is the family of the maximal chains in $P$, then $M_{i}$ is a finite maximal chain in P. Using corollary (3-8), we get : ${ }^{g}{ }^{h}=x$ for all $x \in M_{i},(g, h) \in G \times H$ with $1 \leq \mathrm{i} \leq \mathrm{n}$.

Therefore, from part one, the action of $(\mathrm{G}, \mathrm{H})$ on $\mathrm{P}$ is the trivial action only.

\section{Definition (4-6):}

Let $\left(\mathrm{H},{ }^{*} \mathrm{op}\right)$ be a group. Define $\mathrm{H}^{\mathrm{op}}$ to be a group its elements are the element of $\mathrm{H}$ and the product $\mathrm{h}_{1} * \mathrm{op} \mathrm{h}_{2}=\mathrm{h}_{2} * \mathrm{~h}_{1}$.

\section{Proposition (4-7):}

Let $\mathrm{P}$ be a $(\mathrm{G}, \mathrm{H})$-poset, so for all $(\mathrm{g}, \mathrm{h}) \in \mathrm{G} \times \mathrm{H}$ there exists a permutation $\mathrm{g} \rho \mathrm{h}$ : $\mathrm{P} \rightarrow \mathrm{P}$ defined by $\mathrm{g} \rho \mathrm{h}(\mathrm{p})={ }^{\mathrm{g}} \mathrm{p}^{\mathrm{h}}$ for all $\mathrm{p} \in \mathrm{P}$.

Also the map $\rho:\left(\mathrm{G} \times \mathrm{H}^{\mathrm{op}}\right) \rightarrow \mathrm{S}_{|\mathrm{P}|}$ is defined by: $\rho(\mathrm{g}, \mathrm{h})=\mathrm{g} \rho \mathrm{h}$ for all $(\mathrm{g}, \mathrm{h}) \in \mathrm{G} \times \mathrm{H}$ is a homomorphism . 


\section{Proof:}

Similar to the proof in [8] .

Hence, from every $(\mathrm{G}, \mathrm{H})$-poset, we can get a $\left(\mathrm{G} \times \mathrm{H}^{\mathrm{op}}\right)$-poset by the action ${ }^{(\mathrm{g}, \mathrm{h})} \mathrm{p}=$ ${ }^{\mathrm{g}} \mathrm{p}^{\mathrm{h}} \forall \mathrm{g} \in \mathrm{G}, \mathrm{h} \in \mathrm{H}, \mathrm{p} \in \mathrm{P}$.

\section{Definition (4-8):} injective.

A $(\mathrm{G}, \mathrm{H})$-poset is called injective if the corresponding homomorphism $\rho$ is

\section{Proposition (4-9):}

Let $P(M)=\left\{M_{1}, M_{2}, \ldots, M_{n}\right\}$ be the set of the maximal chains in the $(G, H)$-poset P. Let ${ }^{\mathrm{g}} \mathrm{M}_{\mathrm{i}}^{\mathrm{h}}=\mathrm{M}_{\mathrm{i}}$, then, ${ }^{\mathrm{g}} \mathrm{M}_{\mathrm{j}}^{\mathrm{h}} \neq \mathrm{M}_{\mathrm{t}}$ for all $j \neq i$.

\section{Proof:}

Suppose that ${ }^{\mathrm{g}} \mathrm{M}_{\mathrm{j}}^{\mathrm{h}}=\mathrm{M}_{\mathrm{i}}$ for some $j \neq i$. Then, ${ }^{\mathrm{g}} \mathrm{M}_{\mathrm{j}}^{\mathrm{h}}={ }^{\mathrm{g}} \mathrm{M}_{\mathrm{i}}^{\mathrm{h}}$ for some $j \neq i$. So $\mathrm{g}^{-1}\left({ }^{\mathrm{g}} \mathrm{M}_{\mathrm{j}}{ }^{\mathrm{h}}\right)^{\mathrm{h}^{-1}}={ }^{\mathrm{g}^{-1}}\left({ }^{\mathrm{g}} \mathrm{M}_{\mathrm{i}}{ }^{\mathrm{h}}\right)^{\mathrm{h}^{-1}}$ for some $j \neq i$.

Hence, $\mathrm{M}_{\mathrm{j}}=\mathrm{M}_{\mathrm{i}}$ for some $j \neq i$. This is a contradiction since $j \neq i$ implies $|P(M)|<n$. Therefore, ${ }^{\mathrm{g}} \mathrm{M}_{\mathrm{j}}^{\mathrm{h}} \neq \mathrm{M}_{\mathrm{t}}$ for all $j \neq i$.

\section{Proposition (4-10):}

Let $P$ be an injective $(G, H)$-poset, and $P(M)=\left\{M_{1}, M_{2}, \ldots, M_{n}\right\}$ be the family of the maximal chains in $P$. Then:

(i) $\left(\left|M_{i}\right|=\left|M_{j}\right|\right.$ if and only if $\left.\mathrm{i}=\mathrm{j}\right)$, implies that $(\mathrm{G}, \mathrm{H})=\{(\mathrm{e}, \mathrm{e})\}$.

(ii) If $\left|M_{1}\right|=\left|M_{2}\right|=\ldots=\left|M_{n}\right|$, then $|(\mathrm{G}, \mathrm{H})| \leq \mathrm{n}$ ! .

(iii) If we reordered the maximal chains such that:

$$
\left|N_{1}\right|=\left|N_{2}\right|=\ldots=\left|N_{r}\right| \neq\left|N_{r+1}\right|=\ldots=\left|N_{t}\right| \neq\left|N_{t+1}\right|=\ldots=\left|N_{n}\right|,
$$

with $\mathrm{N}_{\mathrm{i}} \in \mathrm{P}(\mathrm{M}), 1 \leq \mathrm{i} \leq \mathrm{n}$, then : $|(\mathrm{G}, \mathrm{H})| \leq \mathrm{r}$ ! x (t-r) ! x . . x (n-k)! .

\section{Proof:}

(i) Since $\rho((g, h))=\left({ }^{g} \rho^{h}\right)(p)=p=I(p)$ for all $p \in P$ and $(g, h) \in G \times H$, then $(g, h) \in \operatorname{ker}(\rho)$. $\operatorname{But} \operatorname{ker}(\rho)=\{\mathrm{e}, \mathrm{e}\}$ because $\rho$ is injective .

Then, $(\mathrm{g}, \mathrm{h})=(\mathrm{e}, \mathrm{e})$ for all $(\mathrm{g}, \mathrm{h}) \in \mathrm{G} \times \mathrm{H}$. So, $(\mathrm{G}, \mathrm{H})=\operatorname{ker}(\rho)=\{(\mathrm{e}, \mathrm{e})\}$.

(ii) $\left|M_{1}\right|=\left|M_{2}\right|=\ldots=\left|M_{n}\right|$. So for all $\mathrm{M}_{\mathrm{i}} \in \mathrm{P}(\mathrm{M})$ and $(\mathrm{g}, \mathrm{h}) \in \mathrm{G} \times \mathrm{H}$ there exists some $\mathrm{M}_{\mathrm{t}} \in \mathrm{P}(\mathrm{M})$ such that ${ }^{\mathrm{g}} \mathrm{M}_{\mathrm{j}}^{\mathrm{h}}=\mathrm{M}_{\mathrm{t}}$.From proposition (4-7), we have ${ }^{\mathrm{g}} \mathrm{M}_{\mathrm{j}} \neq \mathrm{M}_{\mathrm{t}}$ for all $j \neq i$

So, the number of permutations on the maximal chains is $n$ !.Now, since $P$ is an injective $(\mathrm{G}, \mathrm{H})$-poset, then $|(\mathrm{G}, \mathrm{H})| \leq \mathrm{n}$ ! .

(iii) Applying (ii) on every part of equal parts of:

$\left|N_{1}\right|=\left|N_{2}\right|=\ldots=\left|N_{r}\right| \neq\left|N_{r+1}\right|=\ldots=\left|N_{t}\right| \neq\left|N_{t+1}\right|=\ldots \neq\left|N_{k+1}\right|=\ldots=\left|N_{n}\right|$

We get the number of permutations on the equal parts are, $\mathrm{r} !,(\mathrm{t}-\mathrm{r}) !, \ldots,(\mathrm{n}-\mathrm{k})$ ! respectively. Using the fundamental principle of counting, the number of the permutations on the maximal chains is $r$ ! $x(t-r) ! x \ldots x(n-k) !$. Since, $P$ is an injective $(\mathrm{G}, \mathrm{H})$-poset,Then, $|(\mathrm{G}, \mathrm{H})| \leq \mathrm{r}$ ! x(t-r)! x . . x (n-k)! . 


\section{$\underline{R E F E R E N C E S}$}

[1] Behrendt. Gerhard, "Automorphism Groups of Covering Posets and of Dense Posets", Proceeding of Edinburgh Mathematical Society (1992) 35, 115-120.

[2] Birkhoff G., "Lattice Theory", Amer. Math. Soc. Coll. Pub. Vol. XXV, Third Edition, (1967).

[3] Hanlon P., "The Incidence Algebra of a Group Reduced Partially Order Set" (1980) Combinatorial Math. 7, Springer. No.829.

[4] Mohammad A.J."On colouring maps and semidirect product groupoids on groupposets". J. Edu. \& Sci., Vol. 19, No.2, (2007), 99-109.

[5] Mohammad A.J. \& Khalel L.A. "Kinds of Crossed Modules",J. Edu. \& Sci., Vol. 22 No. 2. , (2009), 354-369.

[6] Mohammad A.J. \& Mohammad S.A. " $\beta$-operations on Finite Posets", J. Edu. \& Sci., Vol. 19, (1994), 104-114.

[7] Morris I. \& Wensley C.D., "Adams Operations and 2-operations in $\beta$-Rings", Discrete Mathematics, 50, (1984), 253-270.

[8] Rose J.S., “ A Course on Group Theory”, Cambridge University Press, Cambridge, (1978). 